\title{
The Effect of Corporate Governance on Tax Avoidance by Company Size as the Moderating Variable
}

\author{
Prisila Damayanty ${ }^{1}$, Tania Rambe Putri ${ }^{2}$ \\ \{prisild@ rocketmail.com ${ }^{1}$, rambetania1@gmail.com ${ }^{2}$ \} \\ IBI Kosgoro $57^{12}$
}

\begin{abstract}
The purpose of this study is to determine the effect of corporate governance on tax avoidance, and to determine the role of the size in moderating the relationship of corporate governance and tax avoidance. The secondary data collected came from manufacturing industries listed on the Indonesia Stock Exchange for the period of 2016 - 2018. The data was obtained from the annual report of the Indonesia Capital Market Directory and the Indonesia Stock Exchange website. This study uses multiple moderated regression analysis. The results showed that the proportion of audit committees had a negative and significant effect on tax avoidance. Meanwhile, the board of commissioners and institutional ownership do not affect tax avoidance, while the size can moderate the relationship of the audit committee and tax avoidance.
\end{abstract}

Keywords: audit committee, board of commissioners, corporate governance, institutional ownership, tax avoidance, the size

\section{$1 \quad$ Introduction}

The National Budget is a source of state revenue that is planned to increase investment, equity and reduce poverty. The state budget also has an important role in managing the country's economy. Therefore, in 2019, the State Budget has a fair, healthy and independent theme. "Healthy" can be interpreted that the state budget is expected to be maintained its balance characterized by low deficits. "Fair" means the state budget can create jobs, reduce poverty and overcome income disparities by region. National Budget (APBN) consists of state revenues from the tax sector and the non-tax sector. On the other hand, taxes have contributed greatly to the state finances, as evidenced in the 2019 of APBN, tax revenues contributed $82.5 \%$ to state. Therefore, tax revenue is needed, for the development and welfare of the community. Consequently, the state must also improve services, so that people are more easily and motivated to pay taxes.

On the other hand, in the midst of efforts continuously to increase tax revenue, the country faces obstacles, with tax avoidance activities, usually done by 
companies legally. Tax avoidance is the treatment of companies that try to reduce tax obligations by regulating in such a way that their benefit from loopholes in proper tax law provisions. This act of tax avoidance does not actually violate tax laws but is not in line with the objectives of the Taxation Act. In practice, the treatment of tax avoidance is usually done by minimizing the amount of tax obligations that must be paid legally, while illegal business, known as "embezzlement" (tax evasion). So, tax avoidance is an attempt by the company to pay the minimum amount of tax. Astuti and Aryani [2] state that legally, tax avoidance is not illegal or against the law but it is only an act that is not good and is considered negative, because it causes state losses.

In 2016, the world was shocked by the leak of confidential documents from the law firm Mossack Fonseca in Panama known as the Panama Papers. Inside are world leaders, politicians, public officials, drug dealers, celebrities and billionaires involved. The document states that the alleged practice of the flow of illicit funds in the global financial world has secretly taken place systemically. It was originally founded by Shell Corporation, a fictitious company whose legal procedures were established. In its operations, the company does not conduct company transactions, but fictitious transactions by hiding company assets. This activity is clearly as tax avoidance through legal business practices but aims to rob the country because the tax is not paid.

Meanwhile, good corporate governance is a system that regulates the relationship between the roles of the board of commissioners, directors, shareholders and other stakeholders. Agoes [1], states that companies implement good corporate governance practices to avoid business risks by implementing good governance, so that companies have a clear picture in determining the direction of their performance. On the other hand, good corporate governance is a mechanism used by shareholders and creditors in controlling the actions of company managers. Companies that in practice do tax avoidance can provide an explanation that corporate governance has not been carried out optimally by public companies in Indonesia. The corporate governance component, among others, is the board of commissioners who in carrying out their duties are expected to oversee the company in order to create good corporate governance. The audit committee formed by the board of commissioners is expected to carry out supervisory duties, namely the company's internal control. With the existence of an audit committee, it is expected to improve corporate governance for the better. 
Maraya and Yendrawati [20] stated that companies were asked to continue to make improvements and increase competitiveness, nationally and internationally, so as to increase market confidence and increase investment to boost national economic growth. Therefore, the Indonesian government and the IMF continue to introduce the value of corporate governance, because companies that have good governance can increase the level of compliance with their tax obligations [27].

The board of commissioners is an important part of the organizational structure because it has a control function by providing oversight in general and specifically, in accordance with the articles of association and giving consideration to directors. Thus, the board of commissioners in a company is the representative of the owner of the company who is responsible for overseeing the activities of management so that the company's activities are in line with the expectations of the stakeholders. Ariawan and Setiawan [2] state that one measure that the implementation of good corporate governance has been carried out properly is the ability to control and supervise the actions of managers to implement tax saving practices so as to minimize agency costs, thereby affecting companies in implementing tax avoidance.

The Audit Committee is part of the corporate governance mechanism whose functions include controlling and supervising managers in managing the company. As such, the audit committee carries out independent oversight of the financial reporting process and external audits, as well as providing independent oversight of risks and control over the governance process of a company. Damayanti and Susanto [11] added that the Board of Commissioners assigns the task to the audit committee to guarantee the quality of financial statements from errors, so that the financial statements can be trusted. Finally, the audit committee can improve the quality of information in reporting to stakeholders. Therefore, the existence of the audit committee is expected to avoid tax avoidance [26].

On the other hand, institutional ownership is ownership of shares owned by institutions and institutions, such as insurance, investment companies and banks. The presence of institutional ownership is expected to improve the function of supervision better. In the supervision function, it is certainly expected to guarantee the prosperity of the shareholders. On the other hand, the influence of institutional ownership can pressure companies to improve their performance because of their substantial share ownership in the capital market. Ownership structure has an impact on tax management decisions. Khan [16] said that institutional ownership originating from institutional companies, banks, insurance companies and 
investment companies greatly influences the supervision of company management, so that supervision runs effectively to tax avoidance measures.

Companies are required to improve and enhance competitiveness nationally and internationally so as to increase market confidence and can encourage investment flows and sustainable national economic growth. In this connection, the Indonesian government and the International Monetary Fund (IMF) introduced the concept of Good Corporate Governance (GCG). Companies that have good corporate governance mechanisms will be directly proportional to the compliance of the company in meeting its tax obligations [27]. Several previous studies, regarding the effect of corporate governance on tax avoidance, including Maharani and Suardana [22], found that the proportion of the board of commissioners, audit quality has a negative effect on tax avoidance. Sandy and Lukviarman [26] also showed that corporate governance, namely the proportion of independent commissioners, audit quality and audit committee negatively affecting tax avoidance.

The size of the company is a comparison of objects seen from the size of the total scale size of the company's assets. Large-scale companies are companies that have abundant resources in achieving company goals. The greater the amount of assets of a company, the more stable the company is in making a profit. The smaller a company is, the more resources it has. Based on agency theory, large companies can use their resources to compensate agents to reduce the tax burden to maximize company performance [10].

\subsection{Literature Review}

\subsubsection{Tax Avoidance}

Tax avoidance is a way to avoid tax legally, which is usually done by taxpayers by reducing the amount of tax that must be paid. This method violates taxation rules because it exploits the weaknesses of taxation rules. Lim [18] states that tax avoidance can be defined as the utilization of tax provisions in order to save tax payable that is done legally by the company so as to minimize the tax payable that must be paid. Actions like this can certainly affect state tax revenue so that it can result in a reduction in the source of the state budget. Even though the APBN is used to build public facilities and finance government activities. If the state budget is hampered, development will also be hampered. Companies that minimize the amount of tax that must be paid but still within the framework of the tax regulation do not violate tax rules and regulations. Efforts to minimize tax euphemism can be 
referred to as tax planning. The tax planning refers to the business engineering process and taxpayer transactions so that tax debt can be minimized but still within the framework of taxation rules.

Brown [7] states that tax avoidance is different with tax evasion. Tax evasion is related to how companies violate the law because it reduces or eliminates the tax burden, while tax avoidance is a legal way by utilizing taxation loopholes by minimizing tax payments or making transactions that can avoid taxes. Tax avoidance can be linked to tax planning because tax planning also uses legal means to minimize or avoid or even eliminate tax obligations. Tax avoidance is also done by companies by minimizing the amount of tax that is still within the limits of the provisions of tax regulations through tax planning.

\subsubsection{Corporate Governance}

Corporate governance is a concept to improve efficiency through the relationship between shareholders, company management and the board of directors and other stakeholders. Corporate governance can be a means of monitoring performance. Watts [33] stated that corporate governance is one way to limit the opportunistic behavior of management. According to Hastuti [15], corporate governance is expected to provide protection and guarantees for stakeholders, such as shareholders, creditors, the government, customers and other stakeholders. In general, the principles of good corporate governance consist of:

1) Fairness (justice), ensuring the protection of the rights of shareholders, and ensuring the implementation of commitments with investors.

2) Transparency, requires an open information system, timely, clear and can be compared with the financial situation, company management and company ownership.

3) Accountability, explains roles and responsibilities and supports efforts to balance inter-interests, namely between management and shareholders overseen by the Board of Commissioners.

4) Responsibility, ensuring compliance with the rules and regulations that apply as a mirror of compliance with social values.

Corporate governance can also be interpreted as a concept that is based on agency theory about investor rights, when corporate governance can provide hope to investors that they can receive returns on the funds they invest. Corporate governance is believed to provide confidence for investors that managers will 
benefit and will not embezzle, steal or invest funds in unprofitable projects. In this case, corporate governance can reduce agency costs [28].

The implementation of corporate governance can be done internally or externally. Internal processes can be carried out using internal structures and processes, such as shareholders' general meetings, the proportion of independent commissioners and the composition of the board of directors, while external mechanisms can be used through corporate control, ownership structure and market control [13].

\subsubsection{The Company Size}

The size of the company can be determined by calculating the company's total assets. A large company means having a larger amount of assets than a smaller company. Bestivano [6] stated that the total assets of a company can be used as the company size. High value assets owned by a company can indicate that the company has entered a maturity stage, a positive cash flow condition that indicates the company has a good and stable future because it can generate greater profits compared to companies with smaller assets [14].

The size of the company can also be seen from the large assets owned. Through the size of the company, the size of the assets of a company can be seen in the form of total assets. The size of a company certainly greatly influences the capital used in its operational activities. The company's ability to obtain additional capital from external parties when there is a lack of capital in managing the company's operational activities, is also influenced by the size of the company [19].

\subsection{Hypotheses Development}

1.2.1 The influence of the Independent Board of Commissioners on Tax Avoidance

Board of commissioners carries out its duties based on the role and function of supervision and provides advice to the Board of Directors. To be able to do good corporate governance, the role and function of independent commissioners is very important because the company's business activities must indeed be monitored. The role of the board of commissioners can support better management for companies, so as to improve the quality of financial statements [23]. The existence of the board of commissioners can reduce the practice of management fraud in taxation reporting. Based on this explanation the following hypotheses can be obtained:

\section{H1: The board of commissioners has a negative effect on tax avoidance}




\subsubsection{The influence of the Audit Committee on Tax Avoidance}

The audit committee is a body appointed by the board of commissioners to carry out checks and checks as well as research on the performance of the board of directors. The audit committee is also seen as an extension of the board of commissioners in carrying out supervision of the board of directors. In addition, the existence of the audit committee is also intended to carry out the task of controlling management in the process of preparing financial statements, so as to eliminate and avoid fraudulent practices that will harm stakeholders. The audit committee is expected to support the company's efforts in implementing good corporate governance. Annisa and Kurniasih [5], Dewi et.al. [12] stated that the presence of an audit committee can improve corporate governance and can reduce the occurrence of tax avoidance. Based on the explanation, the following hypothesis can be obtained:

\section{H2: The audit committee has a negative effect on tax avoidance.}

\subsubsection{The Effect of Institutional Ownership on Tax Avoidance}

Institutional ownership is the ownership of company shares by certain financial institutions to be able to exercise the authority to manage large amounts of funds on behalf of other institutions proportionally. Institutional ownership is expected to oversee policies and decisions taken by management. Shleifer and Vishny [28] states that the existence of institutional ownership in a company can make management more careful in making decisions, so that opportunistic behavior does not occur. Institutional ownership can avoid tax avoidance behavior. Fadhilah [13] asserts that high institutional ownership can provide effective control to management, so as to reduce agency problems and reduce management opportunities for tax avoidance. Based on the explanation, the hypothesis can be formulated as follows:

\section{H3: Institutional ownership has a negative effect on tax avoidance}

\subsubsection{The Size Moderate the Audit Committee's Relationship to Tax Avoidance}

The size of the company is a scale that can distinguish the size of a company in terms of differences in the size of income, total assets and total capital. The greater the size of the company will show that the company's situation is getting stronger. Basyaib [8] and Tristianto \& Oktaviani [32] in their research on cash 
effective tax rate as a proxy for determining tax avoidance measure stated that the greater the intended value indicates the lower tax avoidance undertaken.

Swingly and Sukartha [29] also mentioned that the company size did not have a positive effect on tax avoidance. Mayangsari [23] also mentioned that corporate governance supports the company's internal control better. The larger the size of the company will have a large audit committee as well, so that it can suppress tax avoidance actions. Based on this explanation, a hypothesis can be formulated as follows:

H4: The Size moderates the relationship of the audit committee with tax avoidance

\section{Research Method and Analysis Data}

\subsection{Research Design and Measurement}

This research is included in a quantitative study using a causality model, which is testing variables that can change other variables or not change variables. The primary data in the form of financial statements that have been audited and published by the Indonesian Capital Market Reference Center (PRPM) and the Indonesian Capital Market Directory (ICMD). The secondary data were collected from the manufacturing industries listed on the Indonesia Stock Exchange in the period of 2016 - 2018, totaling 30 samples. The analysis used is moderated multiple regression.

\subsection{Measurement}

Measurement of the independent and dependent variables obtained are as follows:

Table 1. Variable Measurement

\begin{tabular}{cccc}
\hline Variable & Measurement & Scale \\
\hline Dependent Variable & Tax Avoidance & ETR Cash $=$ & Ratio \\
& & Current tax burden: Profit before tax & \multirow{2}{*}{ Ratio } \\
\hline
\end{tabular}


Commissioners

Audit

Committee

Institutional

Ownership

Number of independent commissioners:

Number of commissioners

$$
\mathrm{KA}=\quad \text { Ratio }
$$

Number of audit committees

$\mathrm{KI}=$

Ratio

Shares owned by institutions:

Number of shares outstanding

Moderating Variable

The Size

Source: Data processed

The data analysis uses multiple regressions with moderating variable. The analysis model uses moderating with the following equations:

$$
\mathrm{TA}=\boldsymbol{\beta 0}+\boldsymbol{\beta 1 . D K I}+\beta 2 . \mathrm{KA}+\beta 3 . \mathrm{KI}+\boldsymbol{\beta 4 . K A} * \text { Size }+\varepsilon \text { it }
$$

Note:

TA: Tax Avoidance, DKI: Independent Board of Commissioners, KA: Audit Committee, KI: Institutional Ownership

\section{$3 \quad$ Results}

Based on testing using SPSS 21, the results are obtained that all variables meet the role of thumb assumptions specified in the classical assumption requirements. All variables tested with secondary data distribution, including descriptive statistical tests, did not cause serious problems with normality, multicollinearity and heteroscedasticity.

\subsection{Hypothesis Test Results}

Based on data processing from the regression model that includes independent and dependent variables using SPSS 21, the results are as follows:

Table 2. Multiple Regression Model and Moderated Regression Analysis (MRA)

\begin{tabular}{llcccc}
\hline Coefficients $^{\mathbf{a}}$ & & & & \\
\hline & Model & $\begin{array}{c}\text { Unstandardized } \\
\text { Coefficients }\end{array}$ & $\begin{array}{c}\text { Standardized } \\
\text { Coefficients }\end{array}$ & t & Sig. \\
\cline { 3 - 5 }
\end{tabular}




\begin{tabular}{ccccccc}
\hline & B & Std. Error & Beta & & \\
\hline 1 & (Constant) & 72,790 & 18,377 & & 3,961 &, 001 \\
DKI &, 145 &, 120 &, 190 & 1,208 &, 238 \\
& & & & & \\
KA & $-23,770$ & 6,417 &,- 654 & $-3,704$ &, 001 \\
KI &,- 030 &, 058 &,- 087 &,- 516 &, 610 \\
& 1,232 &, 469 &, 514 & 2,625 &, 015 \\
\hline
\end{tabular}

Note:

TA: Tax Avoidance, DKI: Independent Board of Commissioners, KA: Audit Committee, KI: Institutional Ownership

From the table above, it can be seen that the regression equation model using moderation developed in this study is as follows:

$$
\mathrm{TA}=72.79+0.145 \mathrm{DKI}-23.770 \mathrm{KA}-0.030 \mathrm{KI}+1,232 \mathrm{KA} * \mathrm{Size}+\mathrm{e}
$$

Note:

TA: Tax Avoidance, DKI: Independent Board of Commissioners, KA: Audit Committee, KI: Institutional Ownership

\subsection{Panel Data Regression Test}

\subsubsection{First Hypothesis Test}

The first hypothesis examines whether the Independent Board of Commissioners has a negative effect on Tax Avoidance. Based on the results of the regression analysis in table 2 it can be seen that the t-value of 1.208 with a significance level of 0.238 , means that the significance level is greater than 0.05 so that the first hypothesis accepts H0. It can be concluded that the Independent Board of Commissioners cannot reduce Tax Avoidance. Thus, the first hypothesis is rejected.

\subsubsection{Second Hypothesis Test}

The second hypothesis examines whether the Audit Committee can have a negative effect on Tax Avoidance. Based on the results of the regression analysis in table 2 it can be seen that the t-value of -3.704 with a significant level of 0.001 , means that the significance level is less than 0.05 so it can be concluded that the Audit Committee has a negative effect on Tax Avoidance. Thus, the second hypothesis is accepted. 


\subsubsection{Third Hypothesis Test}

The third hypothesis examines whether Institutional Ownership has a negative effect on Tax Avoidance. Based on the analysis in Table 2 it is known that the tvalue of - .516 with a significant level of 0.610 means a significance level greater than 0.05 so it can be concluded that Institutional Ownership cannot reduce Tax Avoidance. Thus, the third hypothesis is rejected.

\subsubsection{Fourth Hypothesis Test}

The fourth hypothesis is testing whether The Size can moderate the Audit Committee's relationship with Tax Avoidance. Based on table 2 regression analysis it is known that the $t$-value of 2.625 with a significance level of 0.015 means smaller than the significant level of 0.05 , so it can be concluded that The Size can moderate the Audit Committee's relationship to Tax Avoidance.

\subsection{Determination Coefficient Test}

Table 3. Coefficient Determination

Model Summary

\begin{tabular}{ccccc}
\hline Model & $\mathbf{R}$ & R Square & $\begin{array}{c}\text { Adjusted R } \\
\text { Square }\end{array}$ & $\begin{array}{c}\text { Std. Error of } \\
\text { the Estimate }\end{array}$ \\
\hline 1 &, $671^{\mathrm{a}}$ &, 450 &, 362 & 8,86172 \\
\hline
\end{tabular}

a. Predictors: (Constant), KA*SIZE, DKI, KI, KA

Note:

TA: Tax Avoidance, DKI: Independent Board of Commissioners, KA: Audit Committee, KI: Institutional Ownership

\subsection{Panel Data Regression Test}

The magnitude of the influence of all independent variables, namely Institutional Ownership, Independent Commissioners, Audit Committee on Tax Avoidance obtained by Adj. R-Square of 0.450. This shows the magnitude of the influence of the independent variables on the dependent variable together by $45 \%$ while the rest is influenced by other factors.

\subsection{Model Accuracy Test (F-Test)}

Table 4. F-Test Results 


\begin{tabular}{ccccccc}
\hline & Model & Sum of Squares & df & Mean Square & F & Sig. \\
\hline 1 & Regression & 1605,948 & 4 & 401,487 & 5,113 &, $004^{\mathrm{b}}$ \\
& Residual & 1963,252 & 25 & 78,530 & & \\
& Total & 3569,200 & 29 & & & \\
\hline
\end{tabular}

a. Dependent Variable: TA

b. Predictors: (Constant), KA*SIZE, DKI, KI, KA

Simultaneous coefficient test is used to determine whether all independent variables included in the regression model have a joint or simultaneous effect on the dependent variable. Based on the ANOVA calculations in table 4 it is known that the F-count is 5.113, while the significance is $\alpha=0.05$ so that the F-count> 0.05 . Thus, $\mathrm{H} 0$ is rejected and $\mathrm{H} 1$ is accepted, so there is a significant influence jointly on Tax Avoidance.

\section{Discussion}

\subsection{The influence of the Board of Commissioners on Tax Avoidance}

Board of Commissioners is a board that in carrying out its duties has the function of helping the management of the company and carrying out good governance so that the function and role of the Board of Commissioners is very important in business activities. The board of commissioners is also required to have good faith and prudence in carrying out their functions and duties in accordance with the company's objectives.

The results of statistical analysis indicate that the existence of an Independent Board of Commissioners does not have a significant negative effect on Tax Avoidance. This is due to the presence of the board of commissioners being ineffective in preventing the practice of tax avoidance, so the board of commissioners is not optimally carrying out a good oversight function in making tax decisions. The existence of the board of commissioners has not been able to influence the practice of tax avoidance of a company. There are allegations that the existence of the board of commissioners is only to meet regulatory requirements, but in carrying out their duties it cannot be effective in preventing tax avoidance practices. 


\subsection{The influence of the Audit Committee on Tax Avoidance}

The audit committee has been used as a component of corporate governance in a public company. Its existence is to oversee the process of making financial reports and internal controls. The audit committee in carrying out its duties is also expected to have adequate knowledge and understanding of financial statements and the principles of internal control.

The results of the statistical analysis show that the existence of the audit committee has a negative effect on tax avoidance. The existence of an audit committee can also increase the integrity and credibility of financial statements [30], so as to reduce the practice of tax avoidance.

\subsection{The Effect of Institutional Ownership on Tax Avoidance}

Institutional ownership has an important role in overseeing and disciplining management. Shleifer and Vishney [28] stated that the institutional ownership can force managers not to take actions that only benefit themselves. Institutional ownership has fiduciary responsibilities, so they can have incentives to ensure management's actions in directing the company to the welfare of shareholders.

The results of statistical tests show that institutional ownership does not affect negative effect on tax avoidance. This can occur because institutional ownership believes that the company's commissioners will carry out their duties and functions properly. This weakness makes the existence of institutional ownership cannot reduce the practice of tax avoidance. The results of this study are in line with Fadhilah [13].

\subsection{The effect of The Size in moderating the relationship of the Audit Committee with Tax Avoidance}

The audit committee is a body appointed by the board of commissioners to carry out checks and examinations and research which is considered to be important for the board of directors in carrying out their duties and functions. While the size of the company is seen from the size of the assets owned.

Statistical test results show that the size can moderate the audit committee's negative relationship to tax avoidance. This is a result of the larger companies, the greater the number of audit committees, so it is expected that with more audit committees in large companies, compared to smaller companies, the size can moderate the negative relationship between audit committees and tax avoidance. 


\section{$5 \quad$ Conclusion and Limitation}

\subsection{Conclusion}

Research results show that the existence of an independent board of commissioners does not have a negative effect on tax avoidance. This shows that the existence of the board of commissioners is not effective in preventing the practice of tax avoidance, because the existence of the board of commissioners is not optimal in carrying out tax supervision.

The existence of an audit committee has a significant negative effect on the practice of tax avoidance because the role of the audit committee in overseeing the process of preparing financial statements and applying the principles of internal control can run effectively, so as to improve the quality of financial statements, which in turn can reduce the practice of tax avoidance.

Institutional ownership does not affect negative effect on tax avoidance. This is because institutional ownership believes that the company's commissioners will carry out their duties and functions properly, including by implementing good governance. This weakness means that institutional ownership cannot reduce tax avoidance practice. The final conclusion is that the size can apparently moderate the audit committee's negative relationship with tax avoidance. This means that the larger the company will have a larger number of audit committees than smaller companies, so that the size of a company can moderate the negative relationship of the audit committee with tax avoidance.

\subsection{Limitation}

Researcher's view of the size that can moderate the negative relationship between the audit committee on tax avoidance is not optimal, it still needs further study. In research, only taking a limited sample, so it cannot be generalized. A sample of 30 pieces from a number of years of observation is considered still far away to be a strict conclusion, so that more samples are needed to get more accurate results. 


\section{References}

[1] Agoes, E. R. (2006). INDONESIA'S LAWS AND REGULATIONS CONCERNING POLLUTION OF THE SEA BY OIL: CASE STUDIES ON COMPENSATION FOR OIL POLLUTION DAMAGES. Prevention and Compensation of Marine Pollution Damage: Recent Developments in Europe, China and the US, 9, 99.

[2] Ariawan, I. M. A. R., \& Setiawan, P. E. (2017). Pengaruh Dewan Komisaris Independen, Kepemilikan Institusional, Profitabilitas dan Leverge Terhadap Tax Avoidance. E-Jurnal Akuntansi, 18(3), 1831-1859.

[3] Astuti, TP, \& Aryani, Y. A. (2017). "Trends In Manufacturing Company Tax Avoidance In Indonesia Registered on BEI Year 2001-2014”. Journal of Accounting, 20 (3), 375-388. https://doi.org/10.24912/ja.v20i3.4

[4] Armstrong, C.S., Blouin, J.L., Jagolinzer, A.D., Larcker, D.F. (2015), Corporate governance, incentives, and tax avoidance. Journal of Accounting and Economics, 60(1), 1-17.

[5] Annisa, N. A., L. Kurniasih. 2012. "The Effect of Good Corporate Governance on Tax Avoidance". Journal of Accounting and Auditing. Universitas Sebelas Maret.

[6] Bestivano, Wildham. 2013. "Effect of Company Size, Company Age, Profitability and Financial Leverage on Income Smoothing in Companies Listed on the Indonesia Stock Exchange ".

[7] Brown, K. B. (2012). A Comparative Look at Regulation of Corporate Tax Avoidance. New York: Springer.

[8] Basyaib, F. (2007). Risk Management. Jakarta: PT Grasindo.

[9] Chen, S. (2010). “Are Family Firms More Tax Aggresive than Non-Family Firms?” Journal of Financial Economics. Vol. 95, Hal. 41-61.

[10] Dharma, IMS, \& Ardiana, PA (2016). "The Effect of Leverage, Fixed Asset Intensity, Company Size, and Political Connections on Tax Avoidance". E-Journal of Accounting. Udayana University, 15 (1), 584-613

[11] Damayanti, F., \& Susanto, T. (2016). "The effect of the Audit Committee, Audit Quality, Institutional Ownership, Corporate Risk d 's Return on Assets on Tax Avoidance ". Essence, 5 (2), 187-206. https://doi.org/10.15408/ess.v5i2.2341

[12] Dewi, Kristiana Ni Nyoman and Ketut Jati. 2014. "Effect of Executive Character, Company Characteristics and Good Corporate Governance Dimensions on Tax Avoidance". Accounting e-journal. Universitas Udayana.

[13] Fadhilah, Rahmi. 2014. "Effects of Good Corporate Governanc e t erhadap Tax Avoidance (Empirical Study on Manufacturing Companies are Registered in Indonesia Stock Exchange 2009-2011). Journal of Accounting. Universitas Negeri Padang, 2 (1)

[14] Hartono, Jogianto. 2015. Investment Theory and Investment Analysis. Yogyakarta: BPFE.

[15] Hastuti, Theresia Dwi. 2005. "Relationship between Good Corporate Governance and Ownership Structure and Financial Performance". SNA VIII Solo, 15-16 September .

[16] Khan, Mozaffar, Suraj Srinivasan, and Liang Tan. 2015. "Institutional Ownership and Corporate Tax Avoidance: New Evidence”. Journal of Accounting. 10 (2), pp: 132-143

[17] Khuruna, I.K. \& William. J. Moser. (2009). "Institutional Ownership and Tax Aggressiveness". AAA 2010 Financial Accounting and Reporting Section (FARS) Paper 
[18] Lim, Y. D. (2011). “Tax Avoidance, Cost of Debt and Shareholder Activism: Evidence from Korea”. Journal of Banking \& Finance 35, 456-470.

[19] Lawi, M. 2016. "Analysis of Effects of Company Size, Profitability, Sales Growth Tax Rate on Capital Structure Islamic Banks in Indonesia in 2013-2014. Journal of Accounting Education. Vol. 01 number 01.

[20] Maraya, AD, \& Yendrawati, R. (2016). " The Effect of Corporate Governance d 's Corporate Social Responsibility Disclosure t erhadap Tax Avoidance: Empirical Study on Mining Companies and CPO ". Indonesian Journal of Accounting \& Auditing, 20 (2), 147-159.

[21] Mashaiekhi, B., Seyyedi, J. (2015), Corporate governance and tax avoidance. Journal of Accounting and Economics, 20, 83-103

[22] Maharani, IGAC, \& Suardana, KA (2014). " The Effect of Corporate Governance, Profitability and Executive Characteristics on Manufacturing Company Tax Avoidance ". E-Journal of Accounting. Universitas Udayana, 2, 525-539.

[23] Mayangsari, Sekar. 2003. " Effect Analysis Independence, Quality Audit s erta Corporate Governance Mechanisms t erhadap Integrity of Financial Statements ". National Symposium on Accounting VI. October 16-17. Surabaya.

[24] " Shell Companies, Cow Piggy Banks, and Tax Avoidance " 12/19/2017 14:16:10 By Mikha Andri, BDK Pekanbaru.

[25] Swingly, C. and Sukartha, IM (2015). " The influence of executive character, the Audit Committee, Company Size, Leverage and Sales Growth p No Tax Avoidance ". E-Journal of Accounting, Universitas Udayana, Bali. Vol. 10, No. 1, Pages: 47-62, ISSN 2302-855

[26] Sandy, S., \& Lukviarman, N. (2015). " Influence of Corporate Governance on Tax Avoidance: Empirical Study p No Manufacturing Company ". Indonesian Journal of Accounting \& Auditing, 19 (2), 85-98.

[27] Sartori, N. 2010. "Effect of Strategic Tax Behaviors on Corporate Governance”. Accesed from WWW.ssrn.com

[28] Shleifer, A. dan R.W. Vishny. 1997. "A Survey of Corporate Governance”. Journal of Finance, Vol 52. No 2. June 737-783.

[29] Swingly, Calvin and Sukartha, I Made. (2015). " The Influence of Executive Character, Audit Committee, Company Size, Leverage, and Sales Growth on Tax Avoidance. " Journal of Accounting. Udayana University

[30] Sriwedari, Tuti. 2009. " Mechanisms of Good Corporate Governance, Profit Management and Financial Performance of Manufacturing Companies on the Indonesia Stock Exchange ". http://eprints.unsut.ac.id

[31] Sandy, S., \& Lukviarman, N. (2015). " Influence of Corporate Governance on Tax Avoidance: Study Empirical on Manufacturing Company ". Indonesian Journal of Accounting \& Auditing, 19 (2), 85-98. https://doi.org/10.20885/jaai.vol19.iss2.art1

[32] Tristianto, D., \& Oktaviani, RM (2016). " Factors Affecting Tax Avoidance with Leverage as Moderation Variables ". Dynamics of Accounting, Finance and Banking, 5 (1), 65-81.

[33] Watts, R.L. 2003. “Conservatism in Accounting Part I: Explanations and Implications”. Accounting Horizons 17. 